\title{
Scurrula ferruginea (Jack) Danser: Therapeutic Applications and Future Opportunities
}

\author{
${ }^{1}$ Safrida, ${ }^{2 *}$ Afwa Hayuningtyas \\ ${ }^{1}$ Nutrition Department, Universitas Teuku Umar, Indonesia, safridam.si@utu.ac.id \\ 2 Nutrition Department, Universitas Teuku Umar, Indonesia, afwahayuningtyas@utu.ac.id \\ *Coresponding author: Safrida, e-mail: safridam.si@utu.ac.id
}

\begin{abstract}
Scurrula ferruginea (Jack) Danser from Loranthaceae is one such mistletoe that grow in tropical countries and has been used as therapeutic agent for curing of diseases, such as anticancer, antihypertensive, antiviral, antimicrobial, antiasthma, anti-hyperglycemic, and analgesic. Regardless of $S$. ferruginea various kinds of health benefits, their available data and literature review are still limited, especially in Indonesia. The scientific studies existence in this review can promote the potency development of S.ferruginea. We suggest critical future opportunities and research directions of S.ferruginea that could improve understanding toward evidence-based medicinal herbs.
\end{abstract}

\section{ARTICLE INFORMATION}

Submitted: $03 / 05 / 2021$

Revised: 25/05/2021

Accepted: 26/05/2021

Publish Online: 27/05/2021

Keywords:
Antihypertensive
Antioxidant Activity
Cytotoxic Activity
Loranthaceae
Scurrula ferruginea (Jack) Danser

How to cite this article: Safrida. Hayuningtyas, Afwa. (2021). Scurrula ferruginea (Jack) Danser: Therapeutic Applications and Future Opportunities. JNS: Journal of Nutrition Science, 2(1), 13-18

\section{Introduction}

Medicinal herbs have been widely used worldwide as traditional medicine. These herbs were chosen as alternative related to their relatively low-price, availability, and use depends on ancestral experience (Ameer et al., 2009). Medicinal plant constitutes a great deal of unused reservoir of drugs. It uses for medicinal and therapeutic purpose for curing of diseases and improve human health (Harvey, 1999; Shakya, 2016). However, several medicinal plants have been used in the treatment of numerous diseases and dietary supplement without proper knowledge of their function. Thus, there is a growing interest in the utilization of medicinal plant which recently researcher intensifying efforts regarding the evaluation of these valuable treasures.

The mistletoes have been recently studied due to their widespread uses as traditional medicine (Hong, Mat Isa, Fakurazi, \& Safinar Ismail, 2020). As hemiparasitic plants, mistletoes possess a distinctive way of life by growing on dicotyledonous plant and attaching to the plant stem with their modified roots called haustorium (Lim et al., 2016). They can survive through their sophisticated system to obtain water and nutrients from the host plants and the ability to do their own photosynthesis (Moghadamtousi, Kamarudin, Chan, Goh, \& Kadir, 2014). Mistletoes may confront variety of responses from their hosts for their hautorial penetration (Okubamichael, Griffiths, \& Ward, 2016). Therefore, it should not be abandoned issue on the medicinal values of hemi-parasitic plant which might be positively or negatively influenced by its host nature. The type and level of chemical compounds and the biological activities of the mistletoe significantly depended on the different host species (Le, Tennakoon, Metali, Lim, \& Bolin, 2016).

Scurrula ferruginea (Jack) Danser, a member of the Loranthaceae family, is one of the mistletoe species. S.ferruginea have been proven to posses several health benefits. Marvibaigi et al. (2014) reported the potent antioxidant activity of $S$. ferruginea which related to treat diseases associated with oxidative stress. Other reports have found that the $S$. ferruginea extract obtained from methanolic extraction shown the result on lowering blood pressure activity, (Ameer et al., 2009). Moreover, phytochemical investigation of $S$. ferruginea has indicated the presence of components from the group of flavonols including quercetin, quercitrin, dan 4-O- 
acetylquercitrin. They performed that quercetin contained in $S$. ferruginea is an active antioxidant responsible to cytotoxic activity which could be further developed on its anticancer activity (F. Lohézic-Le Dévéhat, S. Tomasi, D. Fontanel, \& J. J. Z. f. N. C. Boustie, 2002b).

Other studies investigated other phytochemicals from different mistletoes of Loranthaceae family including alkaloids from African Loranthaceae mistletoe (Tapinanthus dodoneifolius) as antimalarial, antiasthma, vasodilatory, analgesic, antihyperglycemic, and antibacterial (Deeni \& Sadiq, 2002), tannins from South American Loranthaceae mistletoe (Struthanthus vulgaris) as anticancer and antiviral (Cai et al., 2017; Liu et al., 2016), terpenoid from Loranthus micranthus as an antimicrobial agent (Ogechukwu, Ogoamaka, Sylvester, Kawamura, \& Proksch, 2011), and gallic acids from Psittacanthus calyculatus to treat Alzheimer's and Parkinson's diseases (Mansouri et al., 2013). The reports suggesting the future opportunities of $S$. ferruginea on its phytochemical investigation.

Despite S.ferruginea wide range of health benefits, there is limited data and literature review available investigated S.ferruginea, especially from Indonesia. Thus, there is a need to review information that can describe this plant and analyze the relevant scientific publication to add up our knowledge about S.ferruginea. Furthermore, from this review we suggest critical future opportunity and research direction of S.ferruginea that could improve understanding toward evidence based medicinal herbs.

\section{Scurrula ferruginea (Jack) Danser}

Scurrula ferruginea (Jack) Danser, one of the mistletoes species in the Loranthaceae family. S.ferruginea is synonym with Loranthus ferrugineus Roxb. is a plant of a hemi-parasitic mistletoe which adheres to branches or twigs on the various plant, such as coffee, manalagi apple, and jengkol. In Indonesia, S. ferruginea is known as kemladen, benalu, pasilan, ambai-ambai, and tahi burung (De Padua, Bunyapraphatsara, \& Lemmens, 1999)

$S$. ferruginea is a cylindrical woody plant, slender branches that can grow up to $70 \mathrm{~cm}$ in length around the branches have brown hairs. The shape of the leaves is elliptical, which are arranged opposite, the upper of the leaves are glossy, and the lower is brownish fuzzy. The flowers are consist of 4-7 located from the axils. The ovary of brown hairy is found in the flower (Lim et al., 2017). The structural appearance and physical may be slightly different depending on the plant's natural habitat and age. The physical of $S$. ferruginea described in figure 1 (Lim et al., 2016).

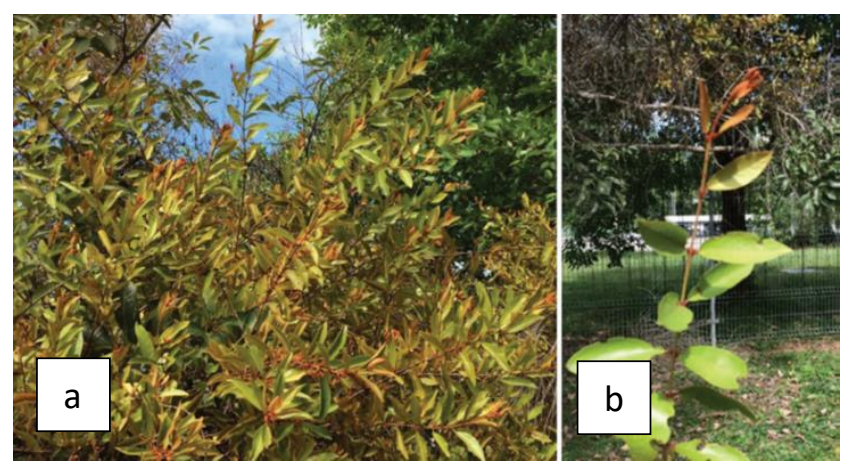

Figure 1. (a) The mistletoe of Scurrula ferruginea attached on a tree (b) A stalk of Scurrula ferruginea mistletoe

S. ferruginea is epiphyte plants that absorb minerals and water from their host causing damage through their complex endophyte system. The type of mineral taken reported including $\mathrm{Mg}, \mathrm{K}, \mathrm{Ca}$, and $\mathrm{Na}$. However, the level proportion of minerals was permeated depends on the Loranthaceae species and its host (Didier et al., 2009). The taxonomical classification of $S$. ferruginea presented in Table 1 (Lim et al., 2016).

Table 1. Taxonomical classification of Scurrula ferruginea (Jack) Danser

\begin{tabular}{ll}
\hline Kingdom & Plantae \\
\hline Phylum & Spermatophyta \\
Class & Magnoliopsida \\
Order & Santalales \\
Family & Loranthaceae \\
Genus & Scurrula \\
Species & Scurrula ferruginea \\
Scientific Name & Scurrula ferruginea Danser \\
\hline
\end{tabular}

\section{Therapeutic Applications of Scurrula ferruginea (Jack) Danser}

\section{A. Antioxidant Activity}

In recent years, there are many diseases associated with oxidative stress, including certain type of cancer, diabetes, coronary heart disease, and the other cardiovascular disease such as high blood pressure, atherosclerosis, and stroke. Those conditions occur from the imbalance between free radical production and neutralization of free radical by antioxidant defense (Liguori et al., 2018). Plant-based 
antioxidants which are derived from natural resources, have been widely used to overcome the problems of oxidative damage. These group of antioxidants have also some advantages including have slight side effects, being reached easily and moderately-priced (Vicas, Socaciu, \& Rugina, 2012). $S$. ferruginea, one such mistletoe which mainly distributed in tropical country, have been investigated on its antioxidant activity which potential to counterbalance the effect of free radical production. A study reported by Ameer et al. (2009), investigated the potential antioxidant activity of $S$. ferruginea extract on blood pressure reduction. The study found that the extract obtained from methanolic extraction shown the best result on lowering blood pressure activity. They also mentioned for possibility of further study to analyze bioactives compounds from $S$. ferruginea that can directly used to treat high blood pressure in human. Another study by LohézicLe Dévéhat et al. (2002b) investigated the phytochemical compounds of $S$. ferruginea. The main antioxidant contain in $S$. ferruginea is the group of flavonoids including quercetin, quercitrin, dan 4O-acetylquercitrin, which were isolated from the ethyl acetate extract. The study also carried out the cytotoxic glycoside evaluation on different cancer cell and found that quercetin shows the most potential cytotoxic activity on U251 (human glioblastoma cells cancer cell line) with IC50 of $35 \mu \mathrm{m}$. Findings from this study performed that quercetin contained in $S$. ferruginea is an active antioxidant which could be further developed on its anticancer activity.

Based on DPPH (2,2-diphenyl-1-picrylhydrazyl) method reported by Marvibaigi et al. (2014), the antioxidant activity of $S$. ferruginea extract varied depending on parts of plant, solvent polarity, and concentration of extracts. Results from this study show that the stem methanol extract exhibited the strongest DPPH radical scavenging (IC50=27.8 $\mu \mathrm{g} / \mathrm{mL})$, highest phenolic $(273.51 \pm 4.84 \mathrm{mg}$ gallic acid/g extract) and flavonoid contents (163.41 \pm 4.62 $\mathrm{mg}$ catechin/g extract). They also reported that methanol extract influenced an increase in ROS generation and the depolarization of mitochondrial, suggesting its potential apoptotic activity. Another study from Marvibaigi reported that the extracts of different parts of $S$. ferruginea especially the stem extract, have a potent antioxidant activity. The stem extract showed a significant antioxidant activity to scavenge free radicals with IC50 value of 19.5 $\mu \mathrm{g} / \mathrm{mL}$. Results from those studies give straight evidence that $S$. ferruginea has a potential antioxidant activity that can be further developed to treat several types of disease associated with oxidative stress.

\section{B. Cytotoxic Activity on Cancer Cell}

The study on the potential of S. ferruginea mistletoe to inhibit cancer cell has been done by F. Lohézic-Le Dévéhat, S. Tomasi, D. Fontanel, and J. Boustie (2002a) shown the $S$. ferruginea extract containing flavonols natural compounds such as glycoside 4-O acetylquercitrin, quercitrin, and quercetin which had the cytotoxic activity on different human cancer cell lines. Quercetin has been found to have the highest cytotoxic activity with $\mathrm{IC}_{50}$ of $35 \mu \mathrm{M}$ on $\mathrm{U} 251$ cells (human glioblastoma cell line).

Some studies have been reported that quercetin are anticancer agent. Xavier, Lima, Rohde, and PereiraWilson (2011) found the quercetin could induce the activity of p53 and Bax on HCT15 cells (colorectal cells). The increase of Bax expression suggesting the apoptosis activation via the intrinsic pathway. Tanigawa, Fujii, and Hou (2008) also found the quercetin could delay the cycle of HepG2 cells (liver cancer cells) in the G2/M phase and induce the apoptotic markers of caspase-3. Apoptosis is a subfamily of cysteine proteases that programmed cell death. Increased apoptotic activity on patients is expected because capable to eliminate cancerous cells or harmful cells thus so as to maintain body tissue homeostasis and control cell proliferation (Safrida, Budijanto, Nuraida, \& Priosoeryanto, 2020). In another study had been reported by Marvibaigi et al., (2016), S. ferruginea v mistletoe extracted by methanol and aqueous had cytotoxic activity on human breast cancer (MDA-MB-231), with IC50 of 19.27 and $50.35 \mu \mathrm{g} / \mathrm{mL}$ respectively. It was capable to inhibit the migration and colony formation of cells. S. ferruginea extract by methanol could induce mitochondria of depolarization and an increase in ROS generation thus result in apoptosis.

Similar to $S$. ferruginea extract, $S$. atropurpurea also possess anticancer activity. Ohashi et al. (2003) evaluated the cytotoxic of S. atropurpurea extract. The bioactive compound of octadeca-8,10,12-triynoic acid was found the most potential to inhibit the invasion of the tumour cells in rats.

\section{Antihypertensive}

Hypertension referred to as high arterial blood pressure abnormally which associated with cardiovascular and kidney disease. It has been identified as the risk factor leading for global mortality. Around 10.4 million deaths per years occur due to hypertension (Unger et al., 2020). 
One of the assorted mistletoes that have been common used in herbal medicine is the family of Loranthaceae. Even though there is a slightly published paper of $S$. ferruginea supporting a lowering activity of blood pressure (Ameer et al 2009; Marvibaigi et al. 2016), within other Loranthaceae family which related species have been many reported for their activity of antihypertensive.

Earlier preliminary identification undertaken by Iwalokun, Hodonu, Nwoke, Ojo, and Agomo (2011) that $L$. micranthus have antihypertensive effects. Here, it was found that extract methanol of $L$. micranthus was partitioned with n-butanol shown the highest antihypertensive activity $\left(\mathrm{EC}_{50}=0.65 \mathrm{mg} / \mathrm{mL}\right.$ and smooth muscle relaxation $\left(\mathrm{R}_{\max }\right)$ of $\left.75.2 \%\right)$ on rat aorta contracting with norepinephrine, then followed by water, chloroform, and ethyl acetate fractions. Additionally, on n-butanol fraction, the cardiac arginase shown reduced by $11.7 \%$, and serum nitric oxide elevated by $55 \%$ in mice with steroids, terpenoids, and tannins assumed to promote these mechanisms. The studied of nitric oxide and cardiac arginase was found that has responsibility for the hypertensive activity.

In Africa, the potency mistletoe herbs of the Loranthaceae family claimed to have antihypertensive activity. It was reported by Obatomi, Aina, and Temple (1996) that given an aqueous L. Bengwensis extract (1.32 g/kg daily) orally to male spontaneously hypertensive rats effectively lowering blood pressure. It was confirmed that $L$. Bengwensis was an antihypertensive agent.

\section{Conclusion and Future opportunities}

$S$. ferruginea have been used traditionally as medicinal herb to treat variety of human diseases in tropical countries. Despite its application as traditional medicine, there was a limited study investigated its application directly to a specific disease.

Previous studies reported the potent therapeutic applications of $S$. ferruginea on its antioxidant activity ( Marvibaigi et al., 2014), blood pressure reduction activity (Ameer et al., 2009), and cytotoxic activity (Lohézic-Le Dévéhat et al., 2002b). However, the details about bioactive compounds related to those therapeutic effects were not mentioned in detailed from the studies. Thus, further analysis on specific bioactive compounds from S.ferruginea that can directly use to treat a disease need to be studied. There was a study by Lohézic-Le Dévéhat et al. (2002a) reported bioactive compounds of S.ferruginea which responsible to cytotoxic activity from the group of flavonoids including quercetin, quercitrin, dan 4-O-acetylquercitrin. They performed that quercetin contained in S.ferruginea is an active antioxidant which could be further developed on its anticancer activity.

Other studies investigated other bioactive compounds from different mistletoes of Loranthaceae family including alkaloids, tannins, terpenoid, and gallic acids. However, isolation of those bioactive compounds from S.ferruginea have not yet been reported. Alkaloids have been isolated from African Loranthaceae mistletoe (Tapinanthus dodoneifolius) (Deeni \& Sadiq, 2002). Tannins have been isolated from South American Loranthaceae mistletoe (Struthanthus vulgaris) and have been found to exert anticancer and antiviral activity (Cai et al., 2017; Liu et al., 2016).

Terpenoids are found in Loranthus micranthus from eastern Nigeria and reported as an antimicrobial agent (Ogechukwu et al., 2011). Gallic acids are found in Psittacanthus calyculatus, a mistletoe from South America and reported to exert Alzheimer's and Parkinson's diseases (Mansouri et al., 2013). Therefore, there are positive opportunities of S.ferruginea as one type of mistletoes from Loranthaceae family to be further studied on its wide range of constituents that provide health benefits.

In the future, when the study on the bioactive compounds contained in S.ferruginea have been clinically proven, it could be further emphasize to its application for supplements or functional food that promote several health benefits.

\section{References}

Ameer, O. Z., Salman, I. M., Yam, M. F., Abd Allah, H. H., Abdulla, M. H., Shah, A. M., Asmawi, M. Z. (2009). Vasorelaxant properties of Loranthus ferrugineus Roxb. methanolic extract. IJP - International Journal of Pharmacology, 5(1), 44-50. doi: 10.3923/ijp.2009.44.50.

Cai, Y., Zhang, J., Chen, N. G., Shi, Z., Qiu, J., He, C., \& Chen, M. J. M. r. r. (2017). Recent advances in anticancer activities and drug delivery systems of tannins. Medicinal Research Reviews, 37(4), 665-701. doi: 10.1002/med.21422.

De Padua, L. S., Bunyapraphatsara, N., \& Lemmens, R. H. M. J. (1999). Plant resources of SouthEast Asia, 12:(1) medicinal and poisonous plants 1: Backhuys Publishers. doi: 10.1021/np990726c. 
Deeni, Y., \& Sadiq, N. J. J. o. E. (2002). Antimicrobial properties and phytochemical constituents of the leaves of African mistletoe (Tapinanthus dodoneifolius (DC) Danser) (Loranthaceae): an ethnomedicinal plant of Hausaland, Northern Nigeria. Journal of Ethnopharmacology, 83(3), 235240. doi: 10.1016/S0378-8741(02)00244-1.

Didier, D. S., Laurier, E. O. N., Din, N., Jules, P. R., Victor, T., Henri, F., Akoa, A. (2009). An assessment on the uses of Loranthaceae in ethno pharmacology in Cameroon: A case study made in Logbessou, North of Douala. Journal of Medicinal Plants Research, 3(8), 592-595.

Harvey, A. L. J. T. i. P. S. (1999). Medicines from nature: are natural products still relevant to drug discovery?, Trends Pharmacol Sci, 20(5), 196-198. doi: 10.1016/s01656147(99)01346-2.

Hong, X., Mat Isa, N., Fakurazi, S., \& Safinar Ismail, I. J. P. A. (2020). Phytochemical and anti-inflammatory properties of Scurrula ferruginea (Jack) Danser parasitising on three different host plants elucidated by NMR-based metabolomics. Wiley: Phytochemical Analysis, 31(1), 15-27. doi: 10.1002/pca.2861.

Iwalokun, B. A., Hodonu, S. A., Nwoke, S., Ojo, O., \& Agomo, P. U. (2011). Evaluation of the possible mechanisms of antihypertensive activity of Loranthus micranthus: an African mistletoe. Biochemistry research international, 2011. doi: 10.1155/2011/159439.

Le, Q. V., Tennakoon, K. U., Metali, F., Lim, L. B., \& Bolin, J. F. J. N. J. o. B. (2016). Host specific variation in photosynthesis of an obligate xylem-tapping mistletoe Dendrophthoe curvata in a Bornean heath forest. Nordic Journal of Botany, 34(2), 235243. doi: 10.1111/njb.00628.

Liguori, I., Russo, G., Curcio, F., Bulli, G., Aran, L., Della-Morte, D., Bonaduce, D. J. C. i. i. a. (2018). Oxidative stress, aging, and diseases. Clinical Interventions in Aging, 13, 757. doi: 10.2147/CIA.S158513.

Lim, Y. C., Rajabalaya, R., Lee, S. H. F., Tennakoon, K. U., Le, Q.-V., Idris, A., David, S. R. J. M. (2016). Parasitic mistletoes of the genera Scurrula and Viscum: from bench to bedside. Molecules 21(8), $1048 . \quad$ doi: 10.3390/molecules21081048.
Liu, C., Cai, D., Zhang, L., Tang, W., Yan, R., Guo, H., \& Chen, X. J. A. r. (2016). Identification of hydrolyzable tannins (punicalagin, punicalin and geraniin) as novel inhibitors of hepatitis B virus covalently closed circular DNA. Antiviral Res, 134, 97-107. doi: 10.1016/j.antiviral.2016.08.026.

Lohézic-Le Dévéhat, F., Tomasi, S., Fontanel, D., \& Boustie, J. (2002a). Flavonols from Scurrula ferruginea danser (Loranthaceae). Zeitschrift für Naturforschung C, 57(11-12), 1092-1096.

Lohézic-Le Dévéhat, F., Tomasi, S., Fontanel, D., \& Boustie, J. J. Z. f. N. C. (2002b). Flavonols from Scurrula ferruginea danser (Loranthaceae). 57(11-12), 1092-1096.

Mansouri, M. T., Farbood, Y., Sameri, M. J., Sarkaki, A., Naghizadeh, B., \& Rafeirad, M. J. F. c. (2013). Neuroprotective effects of oral gallic acid against oxidative stress induced by 6 hydroxydopamine in rats. Food Chemistry, 138(2-3), 1028-1033. doi:10.1016/j.foodchem.2012.11.022.

Marvibaigi, M., Amini, N., Supriyanto, E., Abdul Majid, F. A., Kumar Jaganathan, S., Jamil, S., . . Nasiri, R. J. P. O. (2016). Antioxidant activity and ROS-dependent apoptotic effect of Scurrula ferruginea (Jack) danser methanol extract in human breast cancer cell MDA-MB-231. PLoS One, 11(7), e0158942. doi: 10.1371/journal.pone.0158942.

Marvibaigi, M., Amini, N., Supriyanto, E., Jamil, S., Majid, F. A. A., \& Khangholi, S. J. J. T. (2014). Total phenolic content, antioxidant and antibacterial properties of Scurrula ferruginea $\quad$ extracts. https://www.researchgate.net/publication/27 3311320. doi: 10.11113/jt.v70.3517.

Moghadamtousi, S. Z., Kamarudin, M. N. A., Chan, C. K., Goh, B. H., \& Kadir, H. A. J. T. A. j. o. C. m. (2014). Phytochemistry and biology of Loranthus parasiticus Merr, a commonly used herbal medicine. The American Journal of Chinese Medicine, 42(01), 23-35. doi: 10.1142/S0192415X14500025.

Obatomi, D., Aina, V., \& Temple, V. (1996). Effects of African mistletoe extract on blood pressure in spontaneously hypertensive rats. International Journal of pharmacognosy, 34(2), 124-127. doi: 10.1076/phbi.34.2.124.13197.

Ogechukwu, O. E., Ogoamaka, O. P., Sylvester, N. C., Kawamura, A., \& Proksch, P. J. A. P. j. o. t. m. (2011). Immunomodulatory activity of a 
lupane triterpenoid ester isolated from the eastern Nigeria mistletoe, Loranthus micranthus (Linn). Asian Pac J Trop Med, 4(7), 514-522. doi: 10.1016/S19957645(11)60137-5.

Ohashi, K., Winarno, H., Mukai, M., Inoue, M., Prana, M. S., Simanjuntak, P., \& Shibuya, H. (2003). Indonesian medicinal plants. XXV. Cancer cell invasion inhibitory effects of chemical constituents in the parasitic plant Scurrula atropurpurea (Loranthaceae). Chemical and pharmaceutical bulletin, 51(3), 343-345.

Okubamichael, D. Y., Griffiths, M. E., \& Ward, D. J. A. P. (2016). Host specificity in parasitic plants-perspectives from mistletoes. $A o B$ Plants, 8. doi: 10.1093/aobpla/plw069.

Safrida, S., Budijanto, S., Nuraida, L., \& Priosoeryanto, B. P. (2020). Potency of Bioactive Compound of Rice Bran for Colon Cancer Prevention. KEMAS: Jurnal Kesehatan Masyarakat, 16(2).

Shakya, A. K. J. I. J. o. H. M. (2016). Medicinal plants: Future source of new drugs. International Journal of Herbal Medicine, 4(4), 59-64.

Tanigawa, S., Fujii, M., \& Hou, D.-X. (2008). Stabilization of p53 is involved in quercetininduced cell cycle arrest and apoptosis in HepG2 cells. Bioscience, biotechnology, and biochemistry, 72(3), 797-804.

Unger, T., Borghi, C., Charchar, F., Khan, N. A., Poulter, N. R., Prabhakaran, D., Tomaszewski, M. (2020). 2020 International Society of Hypertension global hypertension practice guidelines. Hypertension, 75(6), 1334-1357.

Vicas, S. I., Socaciu, C., \& Rugina, D. (2012). Antioxidant Activity of European Mistletoe (Viscum Album): Phytochemicals as Nutraceuticals INTECH Open Access Publisher.

Xavier, C. P., Lima, C. F., Rohde, M., \& PereiraWilson, C. (2011). Quercetin enhances 5fluorouracil-induced apoptosis in MSI colorectal cancer cells through p53 modulation. Cancer chemotherapy and pharmacology, 68(6), 1449-1457. doi: 10.1007/s00280-011-1641-9. 